\title{
Inhibiting TRK Proteins in Clinical Cancer Therapy
}

\author{
Allison M. Lange ${ }^{1}$ and Hui-Wen Lo ${ }^{1,2, *}$ \\ 1 Department of Cancer Biology, Wake Forest University School of Medicine, Winston-Salem, NC 27157, USA; \\ amlange9@gmail.com \\ 2 Comprehensive Cancer Center, Wake Forest University School of Medicine, Winston-Salem, NC 27157, USA \\ * Correspondence: hlo@wakehealth.edu
}

Received: 25 February 2018; Accepted: 29 March 2018; Published: 4 April 2018

\begin{abstract}
Gene rearrangements resulting in the aberrant activity of tyrosine kinases have been identified as drivers of oncogenesis in a variety of cancers. The tropomyosin receptor kinase (TRK) family of tyrosine receptor kinases is emerging as an important target for cancer therapeutics. The TRK family contains three members, TRKA, TRKB, and TRKC, and these proteins are encoded by the genes NTRK1, NTRK2, and NTRK3, respectively. To activate TRK receptors, neurotrophins bind to the extracellular region stimulating dimerization, phosphorylation, and activation of downstream signaling pathways. Major known downstream pathways include RAS/MAPK/ERK, PLC $\gamma$, and PI3K/Akt. While being rare in most cancers, TRK fusions with other proteins have been well-established as oncogenic events in specific malignancies, including glioblastoma, papillary thyroid carcinoma, and secretory breast carcinomas. TRK protein amplification as well as alternative splicing events have also been described as contributors to cancer pathogenesis. For patients harboring alterations in TRK expression or activity, TRK inhibition emerges as an important therapeutic target. To date, multiple trials testing TRK-inhibiting compounds in various cancers are underway. In this review, we will summarize the current therapeutic trials for neoplasms involving NTKR gene alterations, as well as the promises and setbacks that are associated with targeting gene fusions.
\end{abstract}

Keywords: NTRK gene fusions; TRKA; TRKB; TRKC; tyrosine kinase inhibitor; cancer; neurotrophin

\section{Introduction}

Mutations or rearrangements in the tropomyosin receptor kinase (TRK) family of receptor tyrosine kinases has recently been described as a mechanism of oncogenesis. The discovery of small molecule TRK inhibitors has generated much excitement in the cancer research community, and early clinical analysis of several compounds has yielded promising results for a variety of cancers. Understanding this family of tyrosine kinase receptors, as well as the related kinase receptor proteins, is essential to developing effective treatments that are targeting gene rearrangements.

The TRK family of receptor tyrosine kinases consists of three members, TRKA, TRKB, and TRKC. These TRK receptors contribute to neuronal development, function, survival, and proliferation during the development and into adulthood [1,2]. Like other receptor tyrosine kinases, TRK proteins are activated following ligand binding to the extracellular domain of the receptor. Ligands for TRK proteins are the neurotrophins, a family of closely-related secreted proteins that were discovered and classified initially as proteins that were able to promote differentiation and survival in both sympathetic and sensory nerves [2,3]. Signaling via TRK proteins is achieved with specific neurotrophin ligands, which triggers receptor dimerization and phosphorylation, leading to the activation of downstream signaling cascades. Each TRK receptor is activated by a distinct neurotrophin. Nerve growth factor (NGF) stimulates TRKA; brain-derived growth factor (BDGF) and neurotrpphins- $4 / 5$ activate 
TRKB whileneurotrpphins-3 activates TRKC. Structurally, TKR proteins share a similar design with an extracellular ligand binding domain, a transmembrane domain, and an intracellular kinase domain $[4,5]$. Through binding to TRK receptors, neorotrophinss activate Ras, phosphatidylinositol-3 (PI3)-kinase, and phospholipase C- $\gamma 1$ signaling pathways [2]. By this signaling, neurotrophins ultimately regulate cell fate decisions, axon growth, dendrite growth, and pruning. They also have additional subtler roles unrelated to the nervous system. In recent years, three rare human genetic disorders, which resulted in deleterious effects on sensory perception, cognition, and a variety of behaviors, have been shown to be attributable to mutations in BDNF and two of the TRK receptors [6,7]. In addition to the expression in the central nervous system (CNS), TRK proteins have also been identified in non-neuronal normal tissues and cells, including pancreatic beta cells, monocytes, lungs, and bone [8].

TRKA is the founding member and best studied of the TRK family of proteins. TRKA is activated by NGF, which has a well-studied role in the mediation of pain, itch, and inflammation, and the development and maintenance of cholinergic, sympathetic, and sensory neurons [9]. Following NGF binding, TRKA activates cell proliferation pathways, including the Ras/MAPK/ERK and the PLC $\gamma /$ PI3K pathways. Mutations interfering with the function of TRKA in humans have been reported to cause congenital insensitivity to pain with anhidrosis syndrome, as well as, mental retardation and self-mutilating behavior [10,11]. Physiologically, TRKA is expressed in both the developing and adult nervous system where it controls the differentiation and survival of neurons [12]. In colorectal cancer patients, chromosomal rearrangements involving the NTRK1 gene (encoding the TRKA protein) are shown in a small subset of patients and are associated with the constitutive activation of the kinase domain of TRKA. In turn, activated TRKA-fusion proteins are associated with the proliferation and survival in colorectal cancer tumors.

TRKB, encoded by NTRK2, is activated by BDNF and has been shown to promote neural cell plasticity and survival [13]. In humans, TRKB expression is highest in the prefrontal cortex, amygdala, and the occipital lobe [14]. Because of its function and expression, altered TRKB expression is implicated in CNS pathologies. Importantly, reduced TRKB protein is observed in post-mortem samples of Alzheimer's disease patients [6,15,16], as well as, Parkinson's disease [17], demonstrating the importance of TRKB to neuronal survival. Decreased TRKB expression is also observed in patients suffering from major depressive disorder [18] and in the post-mortem analysis of the prefrontal cortex of suicide victims and schizophrenics [7,19-21], indicating that TRKB also has a role in mood stabilization and synaptic signaling. As a treatment target, inhibiting TRKB may have undesirable side effects including ataxia, anhedonia, lethargy, and depression [11].

Similar to TRKA and TRKB, TRKC also promotes neuronal differentiation and survival. Following neurotrophin-3 stimulation TRKC, apoptosis is prevented through the activation of the PI3K/AKT pathway. Mutations in TRKC resulting in an inactive protein have been identified as a cause for the Hirschsprung disease, resulting in the absence of nerve cells in the myenteric and submucosal plexus and causing gastrointestinal complications [22]. TRKC, along with TRKA and TRKB have a recently recognized role in cancer signaling, which is discussed below.

\section{TRK Signaling in Cancer}

While the TRK family of receptors play an essential role in neuronal growth and development, the rearranged state may be a driving force for malignancies. Gene fusions lead to chimeric TRK proteins that either lead to the overexpression of the kinase domain or possess constitutive activity of the kinase function. This rearranged state, either through point mutations, chromosome rearrangements and gene fusions, or deletions, results in the spontaneous ligand-independent dimerization and subsequent activation of signal transduction [23].

Fusions of NTRK proteins have been identified in various solid tumors, including the lung, gastrointestinal tract, thyroid, primary brain tumors, and sarcomas [4]. Besides solid tumors, there have also been reports of hematological malignancies that were driven by NTRK fusions, 
including acute myeloid leukemia (AML) [24]. While NTRK fusion expression in all cancers is rare, it is the defining oncogenic driver and a diagnostic marker in some cancers, including secretory breast carcinoma, congenital infantile fibrosarcoma, and mammary analogue secretory carcinoma [1,5]. The identification of recurrent NTRK gene rearrangements, along with preclinical data demonstrating that these oncogenes drive tumorigenesis has initiated the clinical examination of kinase inhibitors as therapeutic targets. To date, all the known mechanisms of oncogenic TRKA activation (fusions, deletions, and alternative splicing) involve some truncation of the extracellular domain, suggesting the existence of a common regulatory domain in this extracellular region [25].

Besides protein fusions, the neurotrophins themselves have been hypothesized to promote tumor growth, and in vitro studies with tumor lines have demonstrated this capability. Singer et al. showed that NGF is capable of stimulating the proliferation of several glioblastoma cell lines, as well as stimulating the further secretion of NGF [9]. Additionally, NGF has demonstrated a capability for progression of non-neuronal tumors, including pancreatic [26], prostatic [27], lung [28], ovarian [29], and medullary thyroid [30].

\section{TRK Fusion Oncoproteins}

Recognition of gene fusions as drivers for oncogenesis began with the identification of BCR-Abl as an initiator for chronic myelogenous leukemia in 1982 [31]. Since this discovery, fusion genes of kinases have been additionally identified in solid tumors, including non-small cell lung cancer (NSCLC) [32], prostate cancer [33], glioblastoma [34], and lung adenocarcinoma [35]. With advances in massively parallel sequencing of the cancer genome, as well as, the availability of large scale sequencing data, the identification of gene fusions has become more straightforward and more reliable [36]. Regarding NTRK and cancer, gene fusions represent the primary molecular alteration that confers oncogenic behavior. Across all the known gene fusions of TRK proteins, the $3^{\prime}$ region of the NTRK gene is fused with the $5^{\prime}$ region of its fusion partner, and the resulting chimeric protein is then either overexpressed or constitutively active [4] (Table 1).

NTRK fusions were originally identified in 1986 in colon cancer when a TPM3-NTRK1 translocation was detected in a tumor biopsy [37]. Since this observation, gene fusions involving NTRK1, 2, and 3 genes have been documented in 11 specific tumor types, most notably NSCLC, papillary thyroid carcinoma [38], secretory breast cancer [39], and glioblastoma [40,41]. Several NTRK gene fusions have been identified as potential initiators of tumorigenesis, and are present in the majority of certain subtypes. For example, $100 \%$ of all mammary analogue secretory carcinomas (MASC) and 93\% of secretory breast cancers exhibit the ETV6-NTRK3 gene fusion [42]. Interestingly, a recent study reported the identification and the functional characterization of a new SCYL3-NTRK1 fusion gene in a patient with colorectal cancer, which is oncogenic and sensitive to TRKA inhibitors [43]. As sequencing techniques continue to develop, it is expected that more NTRK gene fusions will be identified, renewing interest in TRK proteins as therapeutic targets.

Table 1. Clinically identified and reported NTRK family gene fusions and associated cancers.

\begin{tabular}{cccc}
\hline NTRK Gene & Fusion Protein Partner & Cancer Type & Reference \\
\hline NTRK1 & ARHGEF2 & Glioblastoma & Zheng et al., (2014) [44] \\
\hline NTRK1 & BCAN & Glioblastoma & Kim et al., (2014) [36] \\
& Frattini et al., (2013) [40] \\
\hline NTRK1 & CHTOP & Lung adenocarcinoma & Vaishnavi et al., (2013) [45] \\
\hline NTRK1 & LMNA & Glioblastoma & Zheng et al., (2014) [44] \\
\hline NTRK1 & & AYA sarcoma & Doebele et al., (2015) [46] \\
\hline & & Colorectal & Sartore-Bianchi et al., (2016) [2] \\
\hline & & Congenital infantile fibrosarcoma & Wong et al., (2015) [47] \\
\hline & Spitzoid melanomas & Wiesner et al., (2015) [48]
\end{tabular}


Table 1. Cont

\begin{tabular}{|c|c|c|c|}
\hline NTRK Gene & Fusion Protein Partner & Cancer Type & Reference \\
\hline NTRK1 & MPRIP & Lung adenocarcinoma & Vaishnavi et al., (2013) [45] \\
\hline NTRK1 & NFASC & Glioblastoma & $\begin{array}{l}\text { Kim et al., (2014) [36] } \\
\text { Frattini et al., (2013) [40] }\end{array}$ \\
\hline NTRK1 & PPL & Thyroid carcinoma & Farago et al., (2015) [49] \\
\hline NTRK1 & RABGAP1L & Intrahepatic cholangiocellular carcinoma & Ross et al., (2014) [50] \\
\hline NTRK1 & RFWD2 & Large cell neuroendocrine tumor & Fernandez-Cuesta et al., (2014) [51] \\
\hline NTRK1 & SQSTM1 & Lung adenocarcinoma & Farago et al., (2015) [49] \\
\hline NTRK1 & TFG & Papillary thyroid carcinoma & $\begin{array}{l}\text { Beimfohr et al., (1999) [52] } \\
\text { Greco et al., (2010) [53] }\end{array}$ \\
\hline NTRK1 & TP53 & Spitzoid melanomas & Wiesner et al., (2014) [48] \\
\hline \multirow[t]{3}{*}{ NTRK1 } & TPM3 & Colorectal cancer & $\begin{array}{l}\text { Martin-Zanca et al., (1986) [37] } \\
\text { Creancier et al., (2015) [54] } \\
\text { Ardini et al., (2014) [55] }\end{array}$ \\
\hline & & Glioblastoma & Wu et al., (2014) [41] \\
\hline & & Papillary thyroid carcinoma & $\begin{array}{c}\text { Bongarzone et al., (1989) [38] } \\
\text { Beimfohr et al., (1999) [52] } \\
\text { Butti et al., (1995) [56] }\end{array}$ \\
\hline \multirow[t]{2}{*}{ NTRK1 } & TPR & Papillary thyroid carcinoma & Greco et al., 1992, $1997[57,58]$ \\
\hline & & Colorectal cancer & Creancier et al., 2015 [54] \\
\hline NTRK1 & SCYL3 & Colorectal cancer & Milione et al., 2017 [43] \\
\hline NTRK2 & AFAP1 & Low-grade glioma & Stransky et al., (2014) [59] \\
\hline NTRK2 & AGBL4 & Glioblastoma & Wu et al., (2014) [41] \\
\hline NTRK2 & NACC2 & Pilocytic astrocytoma & Jones et al., (2013) [60] \\
\hline NTRK2 & PAN3 & Head and neck squamous cell carcinoma & $\begin{array}{c}\text { Wu et al., (2014) [41] } \\
\text { Stransky et al., (2014) [59] }\end{array}$ \\
\hline NTRK2 & QKI & Pilocytic astrocytoma & Jones et al., (2013) [60] \\
\hline NTRK2 & TRIM24 & Lung adenocarcinomas & $\begin{array}{c}\text { Wu et al., (2014) [41] } \\
\text { Stransky et al., (2014) [59] }\end{array}$ \\
\hline NTRK2 & VCL & Glioblastoma & Wu et al., (2014) [41] \\
\hline NTRK3 & BTBD1 & Glioblastoma & Wu et al., (2014) [41] \\
\hline \multirow[t]{10}{*}{ NTRK3 } & ETV6 & Acute myelogenous leukemia & $\begin{array}{c}\text { Kralik et al., (2011) [24] } \\
\text { Eguchi et al., (1999) [61] } \\
\text { Knezevich et al., (1998a) [62] }\end{array}$ \\
\hline & & Congenital fibrosarcoma & Knezevich et al., (1998b) [63] \\
\hline & & Congenital mesoblastic nephroma & $\begin{array}{l}\text { Knezevich et al., (1998a) [62] } \\
\text { Rubin et al., (1998) [64] } \\
\text { Watanabe et al., (2002) [65] }\end{array}$ \\
\hline & & Colorectal cancer & Hechtman et al., (2015) [66] \\
\hline & & Ductal carcinoma & $\begin{array}{l}\text { Makretsov et al., (2004) [67] } \\
\text { Arce et al., (2005) [68] } \\
\text { Pinto et al., (2014) [69] }\end{array}$ \\
\hline & & Fibrosarcoma & $\begin{array}{l}\text { Morerio et al., (2004) [70] } \\
\text { Punnett et al., (2000) [71] }\end{array}$ \\
\hline & & Gastrointestinal stromal carcinoma & Brenca et al., (2015) [72] \\
\hline & & Glioblastoma & Wu et al., (2014) [41] \\
\hline & & Mammary analogue secretory carcinoma & $\begin{array}{c}\text { Tognon et al., (2002) [39] } \\
\text { Skalova et al., (2016) [73] } \\
\text { Ito et al., (2015) [74] } \\
\text { Del Castillo (2015) [75] }\end{array}$ \\
\hline & & Papillary thyroid carcinoma & Leeman-Neill et al., (2014) [76] \\
\hline
\end{tabular}




\section{Alternative Splicing and Overexpression of TRK Proteins}

Other molecular alterations to TRK have been reported, but with a lower penetrance. An in-frame deletion of NTRK1 in de novo AML has been reported, but this appears to be sporadic and rare [77]. Likewise, a TRKA alternative splicing event has been observed in neuroblastoma [23]. While being relatively specific to neuroblastoma cells, this splice variant was shown to promote angiogenesis and a stress-resistant phenotype [23]. Interestingly, Tacconelli et al. showed that this splice variant had spontaneous tyrosine kinase activity, contributing to higher PI3K and NFkB activity [23]. With increased sensitivity of alternative splicing detection methodswe expect to see more splice variants identified in the future.

Since NTRK overexpression contributes to tumorigenesis and progression, cancers with aberrant NTRK signaling may benefit from TRK inhibitors. In 2009, Lagadec et al. showed that breast tumors expressed higher levels of TRKA and phospho-TRKA when compared to normal breast tissue [3]. Furthermore, they demonstrated in vitro that TRKA overexpression promoted proliferation, migration, and invasion, and that PI3K-Akt and ERK/MAPK pathways were activated by TRKA to promote this aggressive phenotype. These results were recapitulated in animal models, where xenografted mice with TRKA overexpression had accelerated tumor growth, angiogenesis, and metastasis [3].

Other isolated studies have recognized overexpression of TRKA in neuroblastoma [78] and lung cancer [79]. In a study probing 381 cDNA samples from 22 unique cancers, Narayanan et al. showed 50-1000-fold overexpression of TRKA in 100\% of pheochromocytoma cases, as compared to normal tissue. In another study, TRKA was observed to be overexpressed in cancers of the pancreas $(5 / 17)$, ovary $(7 / 20)$, and esophagus $(9 / 20)$ [80]. Like TRKA, TRKC was also shown to have activating mutations in the breast, lung, colon, and pancreatic cancers. Gene fusions, as well as the overexpression of NTRK3, have also been identified as potential contributors to certain cancers, including medulloblastoma, neuroblastoma, and melanoma [22]. Because NTRK alterations occur in a variety of cancer histologies, investigation and investments in TRK inhibitors may be proven to be a beneficial and revolutionary treatment for these malignancies.

\section{Targeting TRK in Cancer}

Expression of TRKA protein in cancer may confer a more favorable prognosis in certain neoplasms. For example, TRKA expression in neuroblastoma confers a good prognosis via a potential tumor-suppressing role for TRKA and NGF signaling in neuroblastoma cells, resulting in differentiation, growth arrest, and angiogenesis inhibition [78,81-84]. Another study found that higher TRKA expression in neuroblastomas was associated with favorable clinical features, while expression and signaling via TRKC corresponded to a more aggressive and invasive neuroblastoma phenotype [85]. This favorable prognosis may only be relevant for TRKA, and TRKC and TRKB are linked with more aggressive clinical features. TRKB is implicated in the activation of autocrine and paracrine signaling in tumor cells, facilitating angiogenesis and resistance to anticancer drugs [83]. This phenotype has been observed in neuroblastoma, although it is predicted to have relevance across other tumor types $[86,87]$. Furthermore, expression of NTRK1 rearrangements in papillary thyroid cancer also confers a worse prognosis when compared to patients without this fusion gene [88]. However, the introduction and refining of kinase inhibitor therapies, combined with a defined oncogenic target, and the extremely limited appearance of clinical resistance mechanisms, may prove to make NTRK gene alteration cancers may be easier to control.

\section{Clinical Trials Involving TRK Inhibitors}

Identification of fusion genes altering the activity of NTRK kinase domains has prompted interest in developing tyrosine kinase inhibitors specific for these proteins. Interestingly, the kinase domain of TRK proteins is remarkably conserved. TRKB and TRKC share $100 \%$ identical residues in the ATP binding sites, and there is only a 2 of 40 residue deviation between TRKA and TRKB [89]. Because of the 
remarkable conservation, efforts to develop a pan-TRK inhibitor seem more feasible than generating an inhibitor with specificity. For the cancer treatment paradigm, generating a pan-TRK inhibitor translates to broader antitumor activity. Ongoing clinical trials for tyrosine kinase inhibitors involving TRK proteins are outlined in Table 2, and it will be an important task to examine the anti-cancer effects of these compounds.

Table 2. Ongoing clinical trials for patients with NTRK fusions or altered activity.

\begin{tabular}{|c|c|c|c|}
\hline NCT Identifier & Drug & Phase & Cancer Type Indication \\
\hline NCT03213704 & LOXO-101 (Larotrectinib) & II & $\begin{array}{l}\text { Advanced malignant solid neoplasm, malignant } \\
\text { glioma, recurrent central nervous system neoplasms, } \\
\text { childhood neoplasms (ependymoma, malignant germ } \\
\text { cell, medulloblastoma, Non-Hodgkin Lymphoma, } \\
\text { Rhabdomyosarcoma, soft Tissue Sarcoma) Ewing } \\
\text { Sarcoma, glioma, hepatoblastoma, Langerhans cell } \\
\text { histiocytosis, neuroblastoma, osteosarcoma, peripheral } \\
\text { primitive neuroectodermal tumor, refractory Central } \\
\text { Nervous System Neoplasms, Wilms tumors }\end{array}$ \\
\hline NCT02637687 & LOXO-101 (Larotrectinib) & II & Neoplasms and central nervous system neoplasms \\
\hline NCT02576431 & LOXO-101 (Larotrectinib) & II & $\begin{array}{l}\text { NSCLC, Thyroid, Sarcoma, Colorectal, Salivary Gland, } \\
\text { Biliary Tract, primary brain, ductal breast, melanoma, } \\
\text { solid tumors, bile duct astrocytoma, head and neck, } \\
\text { squamous cell, pontine glioma, pancreatic, ovarian, } \\
\text { renal, cholangiocarcinoma, bronchogenic, lung, } \\
\text { thoracic cavity, nevi and melanomas }\end{array}$ \\
\hline NCT02122913 & LOXO-101 (Larotrectinib) & I & Adult solid tumors \\
\hline NCT02568267 & Entrectinib & II & $\begin{array}{l}\text { Breast, cholangiocarcinoma, colorectal, head and Neck, } \\
\text { large-cell anaplastic lymphoma, melanoma, } \\
\text { neuroendocrine, NSCLC, ovarian, pancreatic, papillary } \\
\text { thyroid, primary brain tumors. renal cell carcinoma, } \\
\text { sarcomas, salivary gland, other adult solid tumor }\end{array}$ \\
\hline NCT02097810 & Entrectinib & II & $\begin{array}{l}\text { Locally advanced solid tumors and metastatic solid } \\
\text { tumors }\end{array}$ \\
\hline NCT02650401 & Entrectinib & II & Solid tumors, CNS tumors, and neuroblastoma \\
\hline NCT01639508 & Cabozantinib & II & NSCLC \\
\hline NCT02920996 & Merestinib & II & Carcinoma, NSCLC, and other solid tumors \\
\hline NCT02048488 & TSR-011 & $\mathrm{I} / \mathrm{II}$ & Solid tumors, lymphomas \\
\hline NCT02279433 & DS-6051b & I & Solid tumors, lymphomas \\
\hline NCT02219711 & MGCD516 & I & Advanced cancers \\
\hline NCT01804530 & PLX7486 & I & Solid tumors and tenosynovial giant cell tumors \\
\hline NCT02228811 & DCC-2701 & I & Locally advanced tumors and metastatic solid tumors \\
\hline
\end{tabular}

Entrectinib (RXDX-101 or NMS-E628), is a potent, selective, ATP-competitive inhibitor of the tyrosine kinases TRKA/B/C, c-ros oncogene 1 (ROS1), and anaplastic lymphoma kinase (ALK) that is currently being investigated in multiple phase II studies [1,5]. The results from phase I trials with Entrectinib, namely ALKA-372-001 and STARTRK-1, have been promising and exciting. Patients enrolled in these trials presented a variety of tumors, including breast, renal cell, ovarian, NSCLC, primary brain, and sarcomas [1]. Of the 119 patients that were enrolled, 60 presented a gene rearrangement of NTRK1/2/3, ROS1, or ALK. Point mutations, amplifications, or gene insertions or deletions were observed in 53 patients. Six patients were enrolled, with no known alteration of NTRK1/2/3, ROS1, or ALK. With one exception, no objective response was observed in the patient group without a known alteration of the tyrosine kinases [1].

From this initial phase I trial, a phase II-eligible population was selected based on the presence of a gene fusion involving NTRK1/2/3, ROS1, or ALK and no prior TKI therapy. Of these 25 patients, the three with NTRK1/2/3 rearranged solid tumors experienced an objective response rate of $100 \%$ 
and included NSCLC, colorectal, and glioneural tumors [1]. Patients with ROS-1 rearranged solid tumors demonstrated an objective response rate (ORR) of $86 \%$, including two complete responses and melanoma, and NSCLC. In the remaining seven patients with ALK rearrangements, an ORR of 57\% was achieved, and included NSCLC, renal cell carcinoma, and colorectal cancer. Although the tumor histology varied widely in this study, the median progression-free survival for patients harboring rearrangements in NTRK1/2/3, ROS1, and ALK is 19.0 months. While this median overall survival time point has not been reached, $89.4 \%$ of patients are surviving at 12 months [1].

Remarkably, Entrectinib has demonstrated the efficacy against CNS tumors, indicating the potential and ability for blood-brain barrier penetration [5]. Of the 25 phase II-eligible patients, eight had a primary or metastatic disease that involved the brain. CNS responses were observed in $63 \%$ of these patients. Of note, one patient with 15-20 brain metastases (SQSTM1-NTRK1 NSCLC) had achieved a complete intracranial response that has extended beyond 15 months [1]. Besides, its promising antitumor effects, Entrectinib appears to be well-tolerated in humans. Side effects were mild to moderate and reversible with dose interruption or reduction [1]. The responses observed with Entrectinib treatment demonstrate that NTRK rearrangements are clinically relevant drivers of oncogenic growth. Because of the unsurprising failure of Entrectinib in patients without a tyrosine kinase rearrangement, it is imperative that comprehensive molecular profiling platforms are performed to identify those that would benefit from tyrosine kinase directed therapy.

Like Entrectinib, LOXO-101 (Larotrectinib) is a pan-TRK inhibitor that is capable of penetrating the BBB and is currently tested in multiple phase II clinical trials for tumors with evidence of TRK fusions. Specific neoplasms include glioblastoma, NSCLC, colorectal cancers, melanoma, pancreatic, and ovarian, among others (Table 2). Pharmacokinetically, LOXO-101 has advantageous properties, including good systemic exposure following oral dosing and the $98 \%$ inhibition of TRK receptors at peak concentrations [90]. LOXO-101 showed early promise as an anti-neoplastic therapy in 2015 in a study enrolling six patients with NTRK fusions. In each case, tumors were pathologically advanced and previously pre-treated. All of the patients had confirmed partial responses to LOXO-101 within four months, and one patient with a soft-tissue sarcoma had a near complete response after eight months [91]. Importantly, the responses have proven to be durable and all of the patients are continuing therapy. LOXO-101 also presents a well-tolerated toxicity profile with fatigue, dizziness, and anemia among the most common side effects. As a follow-up to these promising results, LOXO-101 is currently being investigated in a multicenter phase II basket trial for patients with any NTRK-fusion-expressing solid tumor. Drilon et al. recently reported results of a phase I/II clinical trial on larotrectinib/LOXO-101 in children and adults showing its promising use for not only adults, but also children [92]. Because it has proven to be ineffective in patients lacking NTRK alterations, LOXO-101's mechanism appears to be inhibition of genetically rearranged NTRK, although the exact mechanism is yet to be elucidated [91].

Cabozantinib (XL184, Cometriq) is an orally bioavailable small molecule inhibitor of c-Met, RET, ROS1, Alk, VEGFR2, and TRK receptors with approved uses for the treatment of metastatic medullary thyroid cancer and prostate cancer. In 2016, Cabozantinib was approved as an anti-angiogenic therapy for patients with advanced renal cell carcinoma with previous treatment, demonstrating significant improvements in response rates, progression-free survival, and overall survival $[93,94]$. While its use clinically is overwhelmingly used for renal cell carcinoma and metastatic medullary thyroid cancer, data is limited on its efficacy against NTRK fusions. However, with growing interest in TRK as a chemotherapy target, Cabozantinib is currently under investigations for patients harboring NTRK1 gene fusions in advanced NSCLC. While promising data has propelled Cabozantinib into Phase II trials, its reported use for NTRK1 fusions is limited. Because Cabozantinib has a dual capacity to inhibit angiogenesis and target gene fusions, the impact of this drug to cancer treatment may be substantial. Multiple phase I and II trials are currently underway to evaluate the use for cabozantinib in both brain metastases of various tumors, as well as high-grade gliomas [95]. While data is still 
limited in describing its use for CNS tumors, its demonstrated blood-brain barrier penetrance may prove to be effective for this site.

Merestinib, is an inhibitor of c-Met, TEK, ROS1, and TRK1/2/3 being investigated in several phase II trials for advanced biliary tract cancer, NSCLC, and other various solid tumors. As of late September 2017, merestinib began a phase $1 \mathrm{~b}$ trial for the treatment of bone metastases in breast cancer patients in combination with standard breast cancer therapies. Like other investigations of TRK inhibitors, merestinib exhibited early promise as a tyrosine kinase inhibitor in multiple in vivo cancer models. Besides its clinical trial recruitment for biliary tract cancer and NSCLC, merestinib has also shown potential for treating AML [96]. Currently, merestinib, in combination with the tyrosine kinase inhibitor LY2874455, is recruiting for a Phase II clinical trial for patients with relapsed or refractory AML. While data on the contribution of NTRK fusions in AML is rare, enhanced detection methods for gene fusions, along with increased exposure of TRK proteins as contributors to oncogenesis, may allow for TRK inhibitors to gain acceptance as a therapy for this cancer.

TSR-011 is an orally bioavailable inhibitor of ALK and TRK receptor tyrosine kinases. Like TRK kinases, ALK gene rearrangements and dysregulated signaling are associated with a growing number of neoplasms. Promising in vitro and in vivo data also suggests a major role in suppressing the oncogenic growth in NSCLC [97]. In early 2014, TSR-011 began a phase I/II open-label, dose-escalation trial (NCT02048488) in patients with advanced solid tumors and lymphomas expressing altered or enhanced TRK or ALK activity [98]. Similar to LOXO-101 and Entrectinib, TSR-011 has had remarkable success in early clinical trials. In a phase I trial, TSR-011 treatment in patients presenting rearranged ALK or NTRK genes had an objective response rate of $100 \%$ in 46 patients $[98,99]$.

DS-6051b is an orally active inhibitor of ROS and TRK tyrosine kinases that is currently in a Phase I, first-in-human clinical trial (NCT02279433). This study will also investigate the pharmacokinetic profile and the preliminary efficacy in humans, and provide dosing guidelines for subsequent clinical trials. Prerequisites for enrolling in this trial include advanced solid tumors containing ROS1 or NTRK gene rearrangements or advanced solid tumors causing tumor-induced pain.

MGCD516 (Mirati Therapeutics Inc., San Diego, CA, USA) is another multi-kinase inhibitor in a phase $1 / 1 \mathrm{~b}$ clinical trial (NCT02219711) for patients with advanced cancers expressing rearranged MET, RET, AXL, NTRK1, or NTRK3 genes. MGCD516 is also predicted to be effective for treating tumors with activating mutations or amplifications of MET, NTRK2, NTRK3, or DDR2. Regarding tumor type, NSCLC, clear cell renal cell carcinoma, metastatic prostate cancer, and head and neck squamous cell carcinoma are anticipated to be the major histologies [100]. As of 2017, this trial is currently enrolling patients and will hopefully produce exciting response rates for these patients.

PLX7486 (Plexxikon, Berkeley, CA, USA) is currently being investigated as a treatment for any solid tumor, demonstrating an activating NTRK mutation (NCT01804530). This trial encompasses PLX7486 as a single-agent treatment as well as in combination. Because TRKA signaling is implicated in pain, this trial is also being evaluated as a modulator for cancer-related pain [11]. Similar to MGCD516, DCC-2701, and MGCD516 are multi-tyrosine kinase inhibitor with in vitro activity against TRKA and TRKB. DCC-2701 and MGCD516 have both recently entered phase I clinical trials for solid tumors expressing gene fusions, and will hopefully generate promising and durable results.

\section{Resistance to TRK Inhibitors}

Because TRK inhibitors are fairly new to clinical development, information regarding the acquired clinical resistance is scarce. Point mutations in the kinase domain are predicted to affect sensitivity, but few have emerged as being clinically relevant. However, a recent study has documented genetic alterations affecting Entrectinib sensitivity in a patient carrying a LMNA-NTRK1 fusion. To characterize this mechanism of resistance, circulating tumor DNA (ctDNA) was transplanted into immunodeficient mice to generate a patient-derived xenograft [101]. The xenograft was then administered the same treatment until resistance emerged, and two novel NTRK protein point mutations were observed. In the kinase domain of the protein, G595R and G667C were observed 
to emerge in these mice [101]. While these point mutations arose in a patient-derived xenograft following entrectinib administration, this preclinical observation of acquired resistance may emerge as clinically relevant, as clinical trials progress and as identification of gene fusions develops. A recent study showed G667C mutation-expressing entrectinib-resistant brain-metastatic colon cancer of cells responded to another NTRK1 inhibitor foretinib [102]. Combining existing cancer treatments, such as foretinib, doxorubicin, cisplatin, and irinotecan with TRK inhibitors could potentially overcome entrectinib resistance, although clinical data regarding combination treatments is still lacking.

\section{Conclusions}

While TRK proteins serve a vital role in CNS development and survival, the aberrant signaling of TRK proteins is implicated in a variety of malignancies. The identification of NTRK fusions and mutations as oncogenic contributors has revealed opportunities for therapeutic intervention. The early clinical success of molecules, such as LOXO-101, Entrectinib, and Cabozantinib have shown that the therapeutic target can potentially more important than the tumor organ when selecting a treatment. As technologies allow for more gene rearrangement data, therapies can be better planned to target the oncogenic contributor. Although TRK inhibitor research is in its early stage of clinical evaluation, the future appears promising for patients with TRK mutations and the field of molecularly targeted therapies.

Acknowledgments: We acknowledge the financial support from the NIH; R01NS087169 (Hui-Wen Lo), and the DoD, W81XWH-17-1-0044 (Hui-Wen Lo).

Conflicts of Interest: The authors declare no conflict of interest. The founding sponsors had no role in the design of the study; in the collection, analyses, or interpretation of data; in the writing of the manuscript, and in the decision to publish the results.

\section{References}

1. Drilon, A.; Siena, S.; Ou, S.I.; Patel, M.; Ahn, M.J.; Lee, J.; Bauer, T.M.; Farago, A.F.; Wheler, J.J.; Liu, S.V.; et al. Safety and Antitumor Activity of the Multitargeted Pan-TRK, ROS1, and ALK Inhibitor Entrectinib: Combined Results from Two Phase I Trials (ALKA-372-001 and STARTRK-1). Cancer Discov. 2017, 7, 400-409. [CrossRef] [PubMed]

2. Nakagawara, A. Trk receptor tyrosine kinases: A bridge between cancer and neural development. Cancer Lett. 2001, 169, 107-114. [CrossRef]

3. Lagadec, C.; Meignan, S.; Adriaenssens, E.; Foveau, B.; Vanhecke, E.; Romon, R.; Toillon, R.A.; Oxombre, B.; Hondermarck, H.; Le Bourhis, X. TrkA overexpression enhances growth and metastasis of breast cancer cells. Oncogene 2009, 28, 1960-1970. [CrossRef] [PubMed]

4. Amatu, A.; Sartore-Bianchi, A.; Siena, S. NTRK gene fusions as novel targets of cancer therapy across multiple tumour types. ESMO Open 2016, 1, e000023. [CrossRef] [PubMed]

5. Ardini, E.; Menichincheri, M.; Banfi, P.; Bosotti, R.; De Ponti, C.; Pulci, R.; Ballinari, D.; Ciomei, M.; Texido, G.; Degrassi, A.; et al. Entrectinib, a Pan-TRK, ROS1, and ALK Inhibitor with Activity in Multiple Molecularly Defined Cancer Indications. Mol. Cancer Ther. 2016, 15, 628-639. [CrossRef] [PubMed]

6. Allen, S.J.; Wilcock, G.K.; Dawbarn, D. Profound and selective loss of catalytic TrkB immunoreactivity in Alzheimer's disease. Biochem. Biophys. Res. Commun. 1999, 264, 648-651. [CrossRef] [PubMed]

7. Hashimoto, T.; Bergen, S.E.; Nguyen, Q.L.; Xu, B.; Monteggia, L.M.; Pierri, J.N.; Sun, Z.; Sampson, A.R.; Lewis, D.A. Relationship of brain-derived neurotrophic factor and its receptor TrkB to altered inhibitory prefrontal circuitry in schizophrenia. J. Neurosci. 2005, 25, 372-383. [CrossRef] [PubMed]

8. Coppola, V.; Barrick, C.A.; Southon, E.A.; Celeste, A.; Wang, K.; Chen, B.; Haddad, E.-B.; Yin, J.; Nussenzweig, A.; Subramaniam, A.; et al. Ablation of TrkA function in the immune system causes B cell abnormalities. Development 2004, 131, 5185-5195. [CrossRef] [PubMed]

9. Singer, H.S.; Hansen, B.; Martinie, D.; Karp, C.L. Mitogenesis in glioblastoma multiforme cell lines: A role for NGF and its TrkA receptors. J. Neurooncol. 1999, 45, 1-8. [CrossRef] [PubMed] 
10. Indo, Y.; Mardy, S.; Miura, Y.; Moosa, A.; Ismail, E.A.; Toscano, E.; Andria, G.; Pavone, V.; Brown, D.L.; Brooks, A.; et al. Congenital insensitivity to pain with anhidrosis (CIPA): Novel mutations of the TRKA (NTRK1) gene, a putative uniparental disomy, and a linkage of the mutant TRKA and PKLR genes in a family with CIPA and pyruvate kinase deficiency. Hum. Mutat. 2001, 18, 308-318. [CrossRef] [PubMed]

11. Morgensztern, D.; Campo, M.J.; Dahlberg, S.E.; Doebele, R.C.; Garon, E.; Gerber, D.E.; Goldberg, S.B.; Hammerman, P.S.; Heist, R.S.; Hensing, T.; et al. Molecularly targeted therapies in non-small-cell lung cancer annual update 2014. J. Thorac. Oncol. 2015, 10, S1-S63. [CrossRef] [PubMed]

12. Indo, Y. Neurobiology of pain, interoception and emotional response: Lessons from nerve growth factor-dependent neurons. Eur. J. Neurosci. 2014, 39, 375-391. [CrossRef] [PubMed]

13. Tejeda, G.S.; Diaz-Guerra, M. Integral Characterization of Defective BDNF/TrkB Signalling in Neurological and Psychiatric Disorders Leads the Way to New Therapies. Int. J. Mol. Sci. 2017, 18, 268. [CrossRef] [PubMed]

14. Su, A.I.; Wiltshire, T.; Batalov, S.; Lapp, H.; Ching, K.A.; Block, D.; Zhang, J.; Soden, R.; Hayakawa, M.; Kreiman, G.; et al. A gene atlas of the mouse and human protein-encoding transcriptomes. Proc. Natl. Acad. Sci. USA 2004, 101, 6062-6067. [CrossRef] [PubMed]

15. Salehi, A.; Verhaagen, J.; Dijkhuizen, P.A.; Swaab, D.F. Co-localization of high-affinity neurotrophin receptors in nucleus basalis of Meynert neurons and their differential reduction in Alzheimer's disease. Neuroscience 1996, 75, 373-387. [CrossRef]

16. Ferrer, I.; Marin, C.; Rey, M.J.; Ribalta, T.; Goutan, E.; Blanco, R.; Tolosa, E.; Marti, E. BDNF and full-length and truncated TrkB expression in Alzheimer disease. Implications in therapeutic strategies. J. Neuropathol. Exp. Neurol. 1999, 58, 729-739. [CrossRef] [PubMed]

17. Fenner, M.E.; Achim, C.L.; Fenner, B.M. Expression of full-length and truncated TrkB in human striatum and substantia nigra neurons: Implications for Parkinson's disease. J. Mol. Histol. 2014, 45, 349-361. [CrossRef] [PubMed]

18. Krishnan, V.; Nestler, E.J. Linking molecules to mood: New insight into the biology of depression. Am. J. Psychiatry 2010, 167, 1305-1320. [CrossRef] [PubMed]

19. Ernst, C.; Deleva, V.; Deng, X.; Sequeira, A.; Pomarenski, A.; Klempan, T.; Ernst, N.; Quirion, R.; Gratton, A.; Szyf, M.; et al. Alternative splicing, methylation state, and expression profile of tropomyosin-related kinase B in the frontal cortex of suicide completers. Arch. Gen. Psychiatry 2009, 66, 22-32. [CrossRef] [PubMed]

20. Dwivedi, Y.; Rizavi, H.S.; Conley, R.R.; Roberts, R.C.; Tamminga, C.A.; Pandey, G.N. Altered gene expression of brain-derived neurotrophic factor and receptor tyrosine kinase B in postmortem brain of suicide subjects. Arch. Gen. Psychiatry 2003, 60, 804-815. [CrossRef] [PubMed]

21. Weickert, C.S.; Ligons, D.L.; Romanczyk, T.; Ungaro, G.; Hyde, T.M.; Herman, M.M.; Weinberger, D.R.; Kleinman, J.E. Reductions in neurotrophin receptor mRNAs in the prefrontal cortex of patients with schizophrenia. Mol. Psychiatry 2005, 10, 637-650. [CrossRef] [PubMed]

22. Ivanov, S.V.; Panaccione, A.; Brown, B.; Guo, Y.; Moskaluk, C.A.; Wick, M.J.; Brown, J.L.; Ivanova, A.V.; Issaeva, N.; El-Naggar, A.K.; et al. TrkC signaling is activated in adenoid cystic carcinoma and requires NT-3 to stimulate invasive behavior. Oncogene 2013, 32, 3698-3710. [CrossRef] [PubMed]

23. Tacconelli, A.; Farina, A.R.; Cappabianca, L.; Desantis, G.; Tessitore, A.; Vetuschi, A.; Sferra, R.; Rucci, N.; Argenti, B.; Screpanti, I.; et al. TrkA alternative splicing: A regulated tumor-promoting switch in human neuroblastoma. Cancer Cell 2004, 6, 347-360. [CrossRef] [PubMed]

24. Kralik, J.M.; Kranewitter, W.; Boesmueller, H.; Marschon, R.; Tschurtschenthaler, G.; Rumpold, H.; Wiesinger, K.; Erdel, M.; Petzer, A.L.; Webersinke, G. Characterization of a newly identified ETV6-NTRK3 fusion transcript in acute myeloid leukemia. Diagn. Pathol. 2011, 6, 19. [CrossRef] [PubMed]

25. Arevalo, J.C.; Conde, B.; Hempstead, B.L.; Chao, M.V.; Martin-Zanca, D.; Perez, P. TrkA immunoglobulin-like ligand binding domains inhibit spontaneous activation of the receptor. Mol. Cell. Biol. 2000, 20, 5908-5916. [CrossRef] [PubMed]

26. Zhu, Z.; Friess, H.; diMola, F.F.; Zimmermann, A.; Graber, H.U.; Korc, M.; Buchler, M.W. Nerve growth factor expression correlates with perineural invasion and pain in human pancreatic cancer. J. Clin. Oncol. 1999, 17, 2419-2428. [CrossRef] [PubMed]

27. Weeraratna, A.T.; Arnold, J.T.; George, D.J.; DeMarzo, A.; Isaacs, J.T. Rational basis for Trk inhibition therapy for prostate cancer. Prostate 2000, 45, 140-148. [CrossRef] 
28. Ricci, A.; Greco, S.; Mariotta, S.; Felici, L.; Bronzetti, E.; Cavazzana, A.; Cardillo, G.; Amenta, F.; Bisetti, A.; Barbolini, G. Neurotrophins and neurotrophin receptors in human lung cancer. Am. J. Respir. Cell Mol. Biol. 2001, 25, 439-446. [CrossRef] [PubMed]

29. Davidson, B.; Reich, R.; Lazarovici, P.; Ann Florenes, V.; Nielsen, S.; Nesland, J.M. Altered expression and activation of the nerve growth factor receptors TrkA and $\mathrm{p} 75$ provide the first evidence of tumor progression to effusion in breast carcinoma. Breast Cancer Res. Treat. 2004, 83, 119-128. [CrossRef] [PubMed]

30. McGregor, L.M.; McCune, B.K.; Graff, J.R.; McDowell, P.R.; Romans, K.E.; Yancopoulos, G.D.; Ball, D.W.; Baylin, S.B.; Nelkin, B.D. Roles of trk family neurotrophin receptors in medullary thyroid carcinoma development and progression. Proc. Natl. Acad. Sci. USA 1999, 96, 4540-4545. [CrossRef] [PubMed]

31. De Klein, A.; van Kessel, A.G.; Grosveld, G.; Bartram, C.R.; Hagemeijer, A.; Bootsma, D.; Spurr, N.K.; Heisterkamp, N.; Groffen, J.; Stephenson, J.R. A cellular oncogene is translocated to the Philadelphia chromosome in chronic myelocytic leukaemia. Nature 1982, 300, 765-767. [CrossRef] [PubMed]

32. Soda, M.; Choi, Y.L.; Enomoto, M.; Takada, S.; Yamashita, Y.; Ishikawa, S.; Fujiwara, S.; Watanabe, H.; Kurashina, K.; Hatanaka, H.; et al. Identification of the transforming EML4-ALK fusion gene in non-small-cell lung cancer. Nature 2007, 448, 561-566. [CrossRef] [PubMed]

33. Tomlins, S.A.; Rhodes, D.R.; Perner, S.; Dhanasekaran, S.M.; Mehra, R.; Sun, X.W.; Varambally, S.; Cao, X.; Tchinda, J.; Kuefer, R.; et al. Recurrent fusion of TMPRSS2 and ETS transcription factor genes in prostate cancer. Science 2005, 310, 644-648. [CrossRef] [PubMed]

34. Singh, D.; Chan, J.M.; Zoppoli, P.; Niola, F.; Sullivan, R.; Castano, A.; Liu, E.M.; Reichel, J.; Porrati, P.; Pellegatta, S.; et al. Transforming fusions of FGFR and TACC genes in human glioblastoma. Science 2012, 337, 1231-1235. [CrossRef] [PubMed]

35. Ju, Y.S.; Lee, W.C.; Shin, J.Y.; Lee, S.; Bleazard, T.; Won, J.K.; Kim, Y.T.; Kim, J.I.; Kang, J.H.; Seo, J.S. A transforming KIF5B and RET gene fusion in lung adenocarcinoma revealed from whole-genome and transcriptome sequencing. Genome Res. 2012, 22, 436-445. [CrossRef] [PubMed]

36. Kim, J.; Lee, Y.; Cho, H.J.; Lee, Y.E.; An, J.; Cho, G.H.; Ko, Y.H.; Joo, K.M.; Nam, D.H. NTRK1 fusion in glioblastoma multiforme. PLoS ONE 2014, 9, e91940. [CrossRef] [PubMed]

37. Martin-Zanca, D.; Hughes, S.H.; Barbacid, M. A human oncogene formed by the fusion of truncated tropomyosin and protein tyrosine kinase sequences. Nature 1986, 319, 743-748. [CrossRef] [PubMed]

38. Bongarzone, I.; Pierotti, M.A.; Monzini, N.; Mondellini, P.; Manenti, G.; Donghi, R.; Pilotti, S.; Grieco, M.; Santoro, M.; Fusco, A.; et al. High frequency of activation of tyrosine kinase oncogenes in human papillary thyroid carcinoma. Oncogene 1989, 4, 1457-1462. [PubMed]

39. Tognon, C.; Knezevich, S.R.; Huntsman, D.; Roskelley, C.D.; Melnyk, N.; Mathers, J.A.; Becker, L.; Carneiro, F.; MacPherson, N.; Horsman, D.; et al. Expression of the ETV6-NTRK3 gene fusion as a primary event in human secretory breast carcinoma. Cancer Cell 2002, 2, 367-376. [CrossRef]

40. Frattini, V.; Trifonov, V.; Chan, J.M.; Castano, A.; Lia, M.; Abate, F.; Keir, S.T.; Ji, A.X.; Zoppoli, P.; Niola, F.; et al. The integrated landscape of driver genomic alterations in glioblastoma. Nat. Genet. 2013, 45, 1141-1149. [CrossRef] [PubMed]

41. Wu, G.; Diaz, A.K.; Paugh, B.S.; Rankin, S.L.; Ju, B.; Li, Y.; Zhu, X.; Qu, C.; Chen, X.; Zhang, J.; et al. The genomic landscape of diffuse intrinsic pontine glioma and pediatric non-brainstem high-grade glioma. Nat. Genet. 2014, 46, 444-450. [CrossRef] [PubMed]

42. Vaishnavi, A.; Le, A.T.; Doebele, R.C. TRKing down an old oncogene in a new era of targeted therapy. Cancer Discov. 2015, 5, 25-34. [CrossRef] [PubMed]

43. Milione, M.; Ardini, E.; Christiansen, J.; Valtorta, E.; Veronese, S.; Bosotti, R.; Pellegrinelli, A.; Testi, A.; Pietrantonio, F.; Fuca, G.; et al. Identification and characterization of a novel SCYL3-NTRK1 rearrangement in a colorectal cancer patient. Oncotarget 2017, 8, 55353-55360. [CrossRef] [PubMed]

44. Zheng, Z.L.; Liebers, M.; Zhelyazkova, B.; Cao, Y.; Panditi, D.; Lynch, K.D.; Chen, J.X.; Robinson, H.E.; Shim, H.S.; Chmielecki, J.; et al. Anchored multiplex PRC for targeted next-generation sequencing. Nat. Med. 2014, 20, 1479-1484. [CrossRef] [PubMed]

45. Vaishnavi, A.; Capelletti, M.; Le, A.T.; Kako, S.; Butaney, M.; Ercan, D.; Mahale, S.; Davies, K.D.; Aisner, D.L.; Pilling, A.B.; et al. Oncogenic and drug-sensitive NTRK1 rearrangements in lung cancer. Nat. Med. 2013, 19, 1469-1472. [CrossRef] [PubMed] 
46. Doebele, R.C.; Davis, L.E.; Vaishnavi, A.; Le, A.T.; Estrada-Bernal, A.; Keysar, S.; Jimeno, A.; Varella-Garcia, M.; Aisner, D.L.; Li, Y.; et al. An Oncogenic NTRK Fusion in a Patient with Soft-Tissue Sarcoma with Response to the Tropomyosin-Related Kinase Inhibitor LOXO-101. Cancer Discov. 2015, 5, 1049-1057. [CrossRef] [PubMed]

47. Wong, V.; Pavlick, D.; Brennan, T.; Yelensky, R.; Crawford, J.; Ross, J.S.; Miller, V.A.; Malicki, D.; Stephens, P.J.; Ali, S.M.; et al. Evaluation of a Congenital Infantile Fibrosarcoma by Comprehensive Genomic Profiling Reveals an LMNA-NTRK1 Gene Fusion Responsive to Crizotinib. J. Natl. Cancer Inst. 2016, 108. [CrossRef] [PubMed]

48. Wiesner, T.; Kiuru, M.; Scott, S.N.; Arcila, M.; Halpern, A.C.; Hollmann, T.; Berger, M.F.; Busam, K.J. NF1 Mutations Are Common in Desmoplastic Melanoma. Am. J. Surg. Pathol. 2015, 39, 1357-1362. [CrossRef] [PubMed]

49. Farago, A.F.; Le, L.P.; Zheng, Z.; Muzikansky, A.; Drilon, A.; Patel, M.; Bauer, T.M.; Liu, S.V.; Ou, S.H.; Jackman, D.; et al. Durable Clinical Response to Entrectinib in NTRK1-Rearranged Non-Small Cell Lung Cancer. J. Thorac. Oncol. 2015, 10, 1670-1674. [CrossRef] [PubMed]

50. Ross, J.S.; Wang, K.; Gay, L.; Al-Rohil, R.; Rand, J.V.; Jones, D.M.; Lee, H.J.; Sheehan, C.E.; Otto, G.A.; Palmer, G.; et al. New routes to targeted therapy of intrahepatic cholangiocarcinomas revealed by next-generation sequencing. Oncologist 2014, 19, 235-242. [CrossRef] [PubMed]

51. Fernandez-Cuesta, L.; Peifer, M.; Lu, X.; Sun, R.; Ozretic, L.; Seidal, D.; Zander, T.; Leenders, F.; George, J.; Muller, C.; et al. Frequent mutations in chromatin-remodelling genes in pulmonary carcinoids. Nat. Commun. 2014, 5, 3518. [CrossRef] [PubMed]

52. Beimfohr, C.; Klugbauer, S.; Demidchik, E.P.; Lengfelder, E.; Rabes, H.M. NTRK1 re-arrangement in papillary thyroid carcinomas of children after the Chernobyl reactor accident. Int. J. Cancer 1999, 80, 842-847. [CrossRef]

53. Greco, A.; Miranda, C.; Pierotti, M.A. Rearrangements of NTRK1 gene in papillary thyroid carcinoma. Mol. Cell. Endocrinol. 2010, 321, 44-49. [CrossRef] [PubMed]

54. Creancier, L.; Vandenberghe, I.; Gomes, B.; Dejean, C.; Blanchet, J.C.; Meilleroux, J.; Guimbaud, R.; Selves, J.; Kruczynski, A. Chromosomal rearrangements involving the NTRK1 gene in colorectal carcinoma. Cancer Lett. 2015, 365, 107-111. [CrossRef] [PubMed]

55. Ardini, E.; Bosotti, R.; Borgia, A.L.; De Ponti, C.; Somaschini, A.; Cammarota, R.; Amboldi, N.; Raddrizzani, L.; Milani, A.; Magnaghi, P.; et al. The TPM3-NTRK1 rearrangement is a recurring event in colorectal carcinoma and is associated with tumor sensitivity to TRKA kinase inhibition. Mol. Oncol. 2014, 8, 1495-1507. [CrossRef] [PubMed]

56. Butti, M.G.; Bongarzone, I.; Ferraresi, G.; Mondellini, P.; Borrello, M.G.; Pierotti, M.A. A sequence analysis of the genomic regions involved in the rearrangements between TPM3 and NTRK1 genes producing TRK oncogenes in papillary thyroid carcinomas. Genomics 1995, 28, 15-24. [CrossRef] [PubMed]

57. Greco, A.; Pierotti, M.A.; Bongarzone, I.; Pagliardini, S.; Lanzi, C.; Della Porta, G. TRK-T1 is a novel oncogene formed by the fusion of TPR and TRK genes in human papillary thyroid carcinomas. Oncogene 1992, 7, 237-242. [PubMed]

58. Greco, A.; Miranda, C.; Pagliardini, S.; Fusetti, L.; Bongarzone, I.; Pierotti, M.A. Chromosome 1 rearrangements involving the genes TPR and NTRK1 produce structurally different thyroid-specific TRK oncogenes. Genes Chromosomes Cancer 1997, 19, 112-123. [CrossRef]

59. Stransky, N.; Cerami, E.; Schalm, S.; Kim, J.L.; Lengauer, C. The landscape of kinase fusions in cancer. Nat. Commun. 2014, 5, 4846. [CrossRef] [PubMed]

60. Jones, D.T.; Hutter, B.; Jager, N.; Korshunov, A.; Kool, M.; Warnatz, H.J.; Zichner, T.; Lambert, S.R.; Ryzhova, M.; Quang, D.A.; et al. Recurrent somatic alterations of FGFR1 and NTRK2 in pilocytic astrocytoma. Nat. Genet. 2013, 45, 927-932. [CrossRef] [PubMed]

61. Eguchi, M.; Eguchi-Ishimae, M.; Tojo, A.; Morishita, K.; Suzuki, K.; Sato, Y.; Kudoh, S.; Tanaka, K.; Setoyama, M.; Nagamura, F.; et al. Fusion of ETV6 to neurotrophin-3 receptor TRKC in acute myeloid leukemia with $\mathrm{t}(12 ; 15)(\mathrm{p} 13 ; \mathrm{q} 25)$. Blood 1999, 93, 1355-1363. [PubMed]

62. Knezevich, S.R.; Garnett, M.J.; Pysher, T.J.; Beckwith, J.B.; Grundy, P.E.; Sorensen, P.H. ETV6-NTRK3 gene fusions and trisomy 11 establish a histogenetic link between mesoblastic nephroma and congenital fibrosarcoma. Cancer Res. 1998, 58, 5046-5048. [PubMed] 
63. Knezevich, S.R.; McFadden, D.E.; Tao, W.; Lim, J.F.; Sorensen, P.H. A novel ETV6-NTRK3 gene fusion in congenital fibrosarcoma. Nat. Genet. 1998, 18, 184-187. [CrossRef] [PubMed]

64. Rubin, B.P.; Chen, C.J.; Morgan, T.W.; Xiao, S.; Grier, H.E.; Kozakewich, H.P.; Perez-Atayde, A.R.; Fletcher, J.A. Congenital mesoblastic nephroma $\mathrm{t}(12 ; 15)$ is associated with ETV6-NTRK3 gene fusion: Cytogenetic and molecular relationship to congenital (infantile) fibrosarcoma. Am. J. Pathol. 1998, 153, 1451-1458. [CrossRef]

65. Watanabe, N.; Kobayashi, H.; Hirama, T.; Kikuta, A.; Koizumi, S.; Tsuru, T.; Kaneko, Y. Cryptic $t(12 ; 15)(p 13 ; q 26)$ producing the ETV6-NTRK3 fusion gene and no loss of IGF2 imprinting in congenital mesoblastic nephroma with trisomy 11: Fluorescence in situ hybridization and IGF2 allelic expression analysis. Cancer Genet. Cytogenet. 2002, 136, 10-16. [CrossRef]

66. Hechtman, J.F.; Zehir, A.; Yaeger, R.; Wang, L.; Middha, S.; Zheng, T.; Hyman, D.M.; Solit, D.; Arcila, M.E.; Borsu, L.; et al. Identification of Targetable Kinase Alterations in Patients with Colorectal Carcinoma That are Preferentially Associated with Wild-Type RAS/RAF. Mol. Cancer Res. 2016, 14, 296-301. [CrossRef] [PubMed]

67. Makretsov, N.; He, M.; Hayes, M.; Chia, S.; Horsman, D.E.; Sorensen, P.H.; Huntsman, D.G. A fluorescence in situ hybridization study of ETV6-NTRK3 fusion gene in secretory breast carcinoma. Genes Chromosomes Cancer 2004, 40, 152-157. [CrossRef] [PubMed]

68. Arce, C.; Cortes-Padilla, D.; Huntsman, D.G.; Miller, M.A.; Duennas-Gonzalez, A.; Alvarado, A.; Perez, V.; Gallardo-Rincon, D.; Lara-Medina, F. Secretory carcinoma of the breast containing the ETV6-NTRK3 fusion gene in a male: Case report and review of the literature. World J. Surg. Oncol. 2005, 3, 35. [CrossRef] [PubMed]

69. Pinto, A.; Nose, V.; Rojas, C.; Fan, Y.S.; Gomez-Fernandez, C. Searching for mammary analogue [corrected] secretory carcinoma of salivary gland among its mimics. Mod. Pathol. 2014, 27, 30-37. [CrossRef] [PubMed]

70. Morerio, C.; Rapella, A.; Rosanda, C.; Tassano, E.; Conte, M.; Gambini, C.; Panarello, C. Differential diagnosis of congenital fibrosarcoma. Cancer Genet. Cytogenet. 2004, 152, 167-168. [CrossRef] [PubMed]

71. Punnett, H.H.; Tomczak, E.Z.; Pawel, B.R.; de Chadarevian, J.P.; Sorensen, P.H. ETV6-NTRK3 gene fusion in metastasizing congenital fibrosarcoma. Med. Pediatr. Oncol. 2000, 35, 137-139. [CrossRef]

72. Brenca, M.; Maestro, R. Massive parallel sequencing in sarcoma pathobiology: State of the art and perspectives. Expert Rev. Anticancer Ther. 2015, 15, 1473-1488. [CrossRef] [PubMed]

73. Skalova, A.; Vanecek, T.; Simpson, R.H.; Laco, J.; Majewska, H.; Baneckova, M.; Steiner, P.; Michal, M. Mammary Analogue Secretory Carcinoma of Salivary Glands: Molecular Analysis of 25 ETV6 Gene Rearranged Tumors With Lack of Detection of Classical ETV6-NTRK3 Fusion Transcript by Standard RT-PCR: Report of 4 Cases Harboring ETV6-X Gene Fusion. Am. J. Surg. Pathol. 2016, 40, 3-13. [CrossRef] [PubMed]

74. Ito, Y.; Ishibashi, K.; Masaki, A.; Fujii, K.; Fujiyoshi, Y.; Hattori, H.; Kawakita, D.; Matsumoto, M.; Miyabe, S.; Shimozato, K.; et al. Mammary analogue secretory carcinoma of salivary glands: A clinicopathologic and molecular study including 2 cases harboring ETV6-X fusion. Am. J. Surg. Pathol. 2015, 39, 602-610. [CrossRef] [PubMed]

75. Del Castillo, M.; Chibon, F.; Arnould, L.; Croce, S.; Ribeiro, A.; Perot, G.; Hostein, I.; Geha, S.; Bozon, C.; Garnier, A.; et al. Secretory Breast Carcinoma: A Histopathologic and Genomic Spectrum Characterized by a Joint Specific ETV6-NTRK3 Gene Fusion. Am. J. Surg. Pathol. 2015, 39, 1458-1467. [CrossRef] [PubMed]

76. Leeman-Neill, R.J.; Kelly, L.M.; Liu, P.; Brenner, A.V.; Little, M.P.; Bogdanova, T.I.; Evdokimova, V.N.; Hatch, M.; Zurnadzy, L.Y.; Nikiforova, M.N.; et al. ETV6-NTRK3 is a common chromosomal rearrangement in radiation-associated thyroid cancer. Cancer 2014, 120, 799-807. [CrossRef] [PubMed]

77. Tomasson, M.H.; Xiang, Z.; Walgren, R.; Zhao, Y.; Kasai, Y.; Miner, T.; Ries, R.E.; Lubman, O.; Fremont, D.H.; McLellan, M.D.; et al. Somatic mutations and germline sequence variants in the expressed tyrosine kinase genes of patients with de novo acute myeloid leukemia. Blood 2008, 111, 4797-4808. [CrossRef] [PubMed]

78. Eggert, A.; Grotzer, M.A.; Ikegaki, N.; Liu, X.G.; Evans, A.E.; Brodeur, G.M. Expression of the neurotrophin receptor TrkA down-regulates expression and function of angiogenic stimulators in SH-SY5Y neuroblastoma cells. Cancer Res. 2002, 62, 1802-1808. [PubMed]

79. Rikova, K.; Guo, A.; Zeng, Q.; Possemato, A.; Yu, J.; Haack, H.; Nardone, J.; Lee, K.; Reeves, C.; Li, Y.; et al. Global survey of phosphotyrosine signaling identifies oncogenic kinases in lung cancer. Cell 2007, 131, 1190-1203. [CrossRef] [PubMed] 
80. Narayanan, R.; Yepuru, M.; Coss, C.C.; Wu, Z.; Bauler, M.N.; Barrett, C.M.; Mohler, M.L.; Wang, Y.; Kim, J.; Snyder, L.M.; et al. Discovery and preclinical characterization of novel small molecule TRK and ROS1 tyrosine kinase inhibitors for the treatment of cancer and inflammation. PLoS ONE 2013, 8, e83380. [CrossRef] [PubMed]

81. Matsushima, H.; Bogenmann, E. Nerve growth factor (NGF) induces neuronal differentiation in neuroblastoma cells transfected with the NGF receptor cDNA. Mol. Cell. Biol. 1990, 10, 5015-5020. [CrossRef] [PubMed]

82. Lavenius, E.; Gestblom, C.; Johansson, I.; Nanberg, E.; Pahlman, S. Transfection of TRK-A into human neuroblastoma cells restores their ability to differentiate in response to nerve growth factor. Cell Growth Differ. 1995, 6, 727-736. [PubMed]

83. Lucarelli, E.; Kaplan, D.; Thiele, C.J. Activation of trk-A but not trk-B signal transduction pathway inhibits growth of neuroblastoma cells. Eur. J. Cancer 1997, 33, 2068-2070. [CrossRef]

84. Edsjo, A.; Hallberg, B.; Fagerstrom, S.; Larsson, C.; Axelson, H.; Pahlman, S. Differences in early and late responses between neurotrophin-stimulated trkA- and trkC-transfected SH-SY5Y neuroblastoma cells. Cell Growth Differ. 2001, 12, 39-50. [PubMed]

85. Light, J.E.; Koyama, H.; Minturn, J.E.; Ho, R.; Simpson, A.M.; Iyer, R.; Mangino, J.L.; Kolla, V.; London, W.B.; Brodeur, G.M. Clinical significance of NTRK family gene expression in neuroblastomas. Pediatr. Blood Cancer 2012, 59, 226-232. [CrossRef] [PubMed]

86. Asgharzadeh, S.; Pique-Regi, R.; Sposto, R.; Wang, H.; Yang, Y.; Shimada, H.; Matthay, K.; Buckley, J.; Ortega, A.; Seeger, R.C. Prognostic significance of gene expression profiles of metastatic neuroblastomas lacking MYCN gene amplification. J. Natl. Cancer Inst. 2006, 98, 1193-1203. [CrossRef] [PubMed]

87. Nakagawara, A.; Arima-Nakagawara, M.; Azar, C.G.; Scavarda, N.J.; Brodeur, G.M. Clinical significance of expression of neurotrophic factors and their receptors in neuroblastoma. Prog. Clin. Biol. Res. 1994, 385, 155-161. [PubMed]

88. Sciavolino, P.J. NTRK Fusions in Papillary Thyroid Cancer: Expanding Targetable Treatment Options. Target. Oncol. 2016. [CrossRef]

89. Bertrand, T.; Kothe, M.; Liu, J.; Dupuy, A.; Rak, A.; Berne, P.F.; Davis, S.; Gladysheva, T.; Valtre, C.; Crenne, J.Y.; et al. The crystal structures of TrkA and TrkB suggest key regions for achieving selective inhibition. J. Mol. Biol. 2012, 423, 439-453. [CrossRef] [PubMed]

90. Burris, H.A.; Shaw, A.T.; Bauer, T.M.; Farago, A.F.; Doebele, R.C.; Smith, S.; Nanda, N.; Cruickshank, S.; Low, J.A.; Brose, M.S. Pharmacokinetics (PK) of LOXO-101 during the first-in-human phase I study in patients with advanced solid tumors: Interim update. Cancer Res. 2015, 75. [CrossRef]

91. TRK Inhibitor Shows Early Promise. Cancer Discov. 2016, 6, OF4. [CrossRef]

92. Drilon, A.; Laetsch, T.W.; Kummar, S.; DuBois, S.G.; Lassen, U.N.; Demetri, G.D.; Nathenson, M.; Doebele, R.C.; Farago, A.F.; Pappo, A.S.; et al. Efficacy of Larotrectinib in TRK Fusion-Positive Cancers in Adults and Children. N. Engl. J. Med. 2018, 378, 731-739. [CrossRef] [PubMed]

93. Al-Salama, Z.T.; Keating, G.M. Cabozantinib: A Review in Advanced Renal Cell Carcinoma. Drugs 2016, 76, 1771-1778. [CrossRef] [PubMed]

94. Abdelaziz, A.; Vaishampayan, U. Cabozantinib for Renal Cell Carcinoma: Current and Future Paradigms. Curr. Treat. Options Oncol. 2017, 18, 18. [CrossRef] [PubMed]

95. Schiff, D.; Desjardins, A.; Cloughesy, T.; Mikkelsen, T.; Glantz, M.; Chamberlain, M.C.; Reardon, D.A.; Wen, P.Y. Phase 1 dose escalation trial of the safety and pharmacokinetics of cabozantinib concurrent with temozolomide and radiotherapy or temozolomide after radiotherapy in newly diagnosed patients with high-grade gliomas. Cancer 2016, 122, 582-587. [CrossRef] [PubMed]

96. Kosciuczuk, E.M.; Saleiro, D.; Kroczynska, B.; Beauchamp, E.M.; Eckerdt, F.; Blyth, G.T.; Abedin, S.M.; Giles, F.J.; Altman, J.K.; Platanias, L.C. Merestinib blocks Mnk kinase activity in acute myeloid leukemia progenitors and exhibits antileukemic effects in vitro and in vivo. Blood 2016, 128, 410-414. [CrossRef] [PubMed]

97. Awad, M.M.; Shaw, A.T. ALK inhibitors in non-small cell lung cancer: Crizotinib and beyond. Clin. Adv. Hematol. Oncol. 2014, 12, 429-439. [PubMed] 
98. Arkenau, H.T.; Sachdev, J.C.; Mita, M.M.; Dziadziuszko, R.; Lin, C.C.; Yang, J.C.H.; Infante, J.R.; Anthony, S.P.; Voskoboynik, M.; Su, W.C.; et al. Phase (Ph) 1/2a study of TSR-011, a potent inhibitor of ALK and TRK, in advanced solid tumors including crizotinib-resistant non-small cell lung cancer. J. Clin. Oncol. 2015, 33. [CrossRef]

99. Iams, W.T.; Lovly, C.M. Anaplastic Lymphoma Kinase as a Therapeutic Target in Non-Small Cell Lung Cancer. Cancer J. 2015, 21, 378-382. [CrossRef] [PubMed]

100. Borczuk, A.; Paucar, D.; Halmos, B. Has MET met its match? Ann. Transl. Med. 2016, 4, 97. [CrossRef] [PubMed]

101. Russo, M.; Misale, S.; Wei, G.; Siravegna, G.; Crisafulli, G.; Lazzari, L.; Corti, G.; Rospo, G.; Novara, L.; Mussolin, B.; et al. Acquired Resistance to the TRK Inhibitor Entrectinib in Colorectal Cancer. Cancer Discov. 2016, 6, 36-44. [CrossRef] [PubMed]

102. Nishiyama, A.; Yamada, T.; Kita, K.; Wang, R.; Arai, S.; Fukuda, K.; Tanimoto, A.; Takeuchi, S.; Tange, S.; Tajima, A.; et al. Foretinib overcomes entrectinib resistance associated with the NTRK1 G667C mutation in NTRK1 fusion-positive tumor cells in a brain metastasis model. Clin. Cancer Res. 2018. [CrossRef] [PubMed]

(C) 2018 by the authors. Licensee MDPI, Basel, Switzerland. This article is an open access article distributed under the terms and conditions of the Creative Commons Attribution (CC BY) license (http:/ / creativecommons.org/licenses/by/4.0/). 